\title{
The calculative reproduction of social structures - The field of gem mining in Sri Lanka
}

\author{
Chandana Alawattage \\ University of Aberdeen Business School, Aberdeen, Scotland, UK
}

\begin{abstract}
A b s tract
Drawing on Bourdieu's political economy of symbolic forms and symbolic power, and on an ethnography of gem mining rituals in Sri Lanka, this paper aims to provide an empirical illustration of the connection between calculative practices and the social structure of capital. It shows how capital is socially structured around particular fields of reproduction, how the field-specific organisation of capital is implicated in the presence and absence of calculative and control practices, and how calculative templates and procedures, as symbolic systems, simultaneously perform interrelated but distinct functions of cognition, communication and domination. The paper advances the argument that calculative templates and procedures constitute a field-specific logic and they are the symbolic means through which structural properties of the social systems are cognised, communicated, reproduced and transformed into a set of practical dispositions that orient day-to-day work practices, domination and resistance.
\end{abstract}

Key words: Bourdieu; Calculative practices; Absence of accounting; Ethnography; Forms of capital; Gem mining; Habitus; Symbolic forms; Symbolic power; Sri Lanka

\section{Introduction}

Recently, there has been a revitalisation of social structural approaches to the theoretical analyses of organisational practices. In particular, Bourdieu's conceptions of field, practices, habitus and forms of capital have been making increasing inroads into such analyses (e.g. Everett, 2003, 2004; Fogarty, 1998; Goddard, 2004; Kurunmaki, 1999b; Lounsbury, 2008; Lounsbury and Ventresca, 2003; Lukka and Granlund, 2002; Neu, 2006; Neu et al., 2003; Ramirez, 2001; Shenkin and Coulson, 2007; $\mathrm{Xu}$ and $\mathrm{Xu}, 2008$ ). Following this trend, this paper aims to provide an empirical illustration of the connection between calculative practices and the social structure of capital. Using an empirical case of gem mining rituals in Sri Lanka, the paper shows how capital is socially structured around particular fields of reproduction, how the field-specific organisation of capital is implicated in the presence and absence of calculative and control practices, how calculative templates and procedures, as symbolic systems, simultaneously perform interrelated but distinct functions of cognition, communication and domination and, after all, how domination, subjugation and resistance are scripted into day-to-day work practices. The paper advances the argument that calculative templates and procedures constitute a field-specific logic and they are the symbolic means through which the structural properties of social systems are cognised, communicated, reproduced and transformed into a set of dispositions that orient day-to-day work practices, domination and resistance. 
In doing so, with a view to locating it in its literary context, the paper will first introduce the accounting and control literature that draws on Bourdieu. Second, it will introduce Bourdieu's sociology of symbolic forms and symbolic power as the theoretical foundation of the paper. Third, the paper will discuss its methodological propositions and procedures, followed by the empirical work in four separate sections. Empirical sections are organised around the relations in and of production to reveal how field-specific properties of habitus, bodily hexis, doxa and capital are implicated in the presence and absence of calculative and control practices. Finally, the paper concludes with a theoretical synthesis of the empirics.

\section{Bourdieu in accounting literature}

There is an extant body of accounting and control literature that draws on Bourdieu's ideas (see next section for a brief elaboration of his ideas). This body of literature demonstrates a wide variety in its empirical focus and deployment of Bourdieu's concepts. Not surprisingly, much accounting and control research draws mainly on Bourdieu's concept of 'field' to explain how the constitution of cultural and social capital is implicated in selected accounting phenomena. Lee $(1995,1999)$ and Lee and Williams (1999), for example, drawing on Bourdieu's (1988) study of the French academy in the late 1960s, and on the history of the American Accounting Association as an empirical foundation, explain how the existence of an elite group of researchers within the 'field' of US accounting education has contributed to the stratification of its members according to a pole of cultural capital. They also look at the ways in which this stratification has had the potential to influence the knowledge production process and reproductive order of the accounting academy. Ramirez (2001) also draws on the concepts of field and capital, looking especially at how the lack of solidity within the inner hierarchy of the professional accounting field vis-à-vis the overall hierarchy of social fields, helps in an understanding of the failure of a French project of the institutionalisation of accounting before the Second World War. Again concentrating on the accounting profession, Jacobs (2003) draws on Bourdieu's conceptions of education, distinction and class to demonstrate how class discriminations are reproduced within the recruitment practices of the Scottish accounting profession.

Neu et al. (2001) and Cooper et al. (2005) draw on Bourdieu's work to analyse a rather different issue: the functioning of accounting within public policy struggles and the interventional strategies that critical accounting researchers can pursue in making a socio-political critique of the dominating ideologies of state and corporate capitalism. Drawing mainly on Bourdieu's analysis of the functioning of intellectuals and the politics of cultural production, they emphasise the importance of "universal intellectualism" in this regard (see Bourdieu, 1991a; Neu et al., 2001, p. 740). The contemporary political role of critical academic accountants (i.e. active engagement in the outside world) has also been the point of focus for Cooper (2002). She turns towards the academic and political work of Bourdieu (especially The Weight of the World, Bourdieu, 1999) to offer a persuasive critique on our apathy towards active political engagements in policy critiques and social reformations. Taking the case of Clydesbank asbestos sufferers, the tuition fee campaign in Scotland and also the political role that the Centre for Social and Environmental Accounting Research plays in promoting critical ideologies as illustrations, she argues that real world political engagements should have the "double benefit of allowing us to hone our theoretical understanding and gain the satisfaction of knowing that our work is of social benefit" (Cooper, 2002, p. 461).

Shenkin and Coulson's (2007) paper examines a similar theme: the idea of social activism directed against the corporate hegemony. Based on the Boudieuian idea that communication is seen to reflect an asymmetrical power relationship between social agents who constantly struggle over limited resources in a field, they conceptualise the academic field of Social and Environmental Accounting (SEA) as a discursive space within which two philosophical positions compete for 
recognition: the procedural school of SEA and "social activism". However, contrary to the position of Neu et al. (2001) that discourses of pragmatism, appeals to "commonsense", and calls to be "practical" are the dangers of the critical accounting odyssey (see also Cooper, 2002, pp. 460-461), Shenkin and Coulson (2007) seek possibilities for converging the two ideological positions. Accounting academia has also been the 'field' of study for Everett's (2008) analysis of how editorial proximity is implicated in publication success. He relies on Bourdieu's concepts of "rational selfinterest" and a "good-faith economy", which he utilises to see how actors in accounting academia cultivate "preferred taste", the inculcation of which is argued to be a key factor in publication success (pp. 1150-1151). The notion of the "economy of symbolic goods" (Bourdieu, 1998) has been the explanatory tool for the analysis made by Neu et al. (2003) into ethical discourses in the Canadian accounting profession. By conceptualising character-based and rule-based ethical discourses as types of embodied and objective cultural goods, respectively, and by linking these two types of cultural goods to two different cultural goods markets (restricted, anti-economic and widespread economic), respectively, they explain how and why ethical discourses fulfil binding and legitimacy functions. Thus, analysis of the fields of accounting academia and professions has been a popular empirical field for those accounting researchers who draw on Bourdieu.

Kurunmaki (1999a, 1999b) also draws on the notions of field and capital to conceptualise the Finish health care sector as a site of continuous struggle for power and control. She demonstrates how the field is structured as a game between those involved in the functions of financing, production and consumption of health care, how the distribution of differently valued capital in the field is implicated in their chances of winning and losing the game and how that particular distribution of capital is enacted in a transition from professional planning and control to marketbased control. In a recent publication, Oakes and Young (2010) argue that accounting and accountability convert any social space into a contested field in which struggles over symbolic and cultural capital are inevitable and, in relation to the accountability discourses around the American Indian Trust Fund debacle, they demonstrate how symbolic and cultural capitals enable their holders to generate and control discourse around accountability, and use that discourse with authority and ease.

Neu et al. (2006) combine Foucauldian literature on governmentality with Bourdieu's ideas of field and habitus to examine how the World Bank has used an assemblage of information and reporting practices, within accounting/financial expertise, to influence administrative practices in the field of Latin American education. They demonstrate how information can be fabricated, in a field-specific manner, via the intersection of the newly implanted financial technologies, the pre-existing information systems, and the taken-for-granted habitus of the field. The same synthesis between Foucauldian and Bourdieuian ideas has also been the sociological framework for Neu's (2006) examination of how accounting is implicated in the ordering of the public space. His analysis highlights how the financial and accountability mechanisms used by a Canadian provincial government as part of its educational reform initiatives facilitated changes in the types and amounts of capital of certain field participants, encouraged the partitioning of generic social groupings (such as parents and academic labour) into more finely distinguished social groupings, and introduced new ways of saying and doing into the field (p. 391). Rahaman et al. (2007) also mobilise the same theoretical synthesis to demonstrate, using the case of the privatisation of water services in Ghana, how accounting and its users provide external agencies, such as the World Bank, with a source of symbolic capital as a means of controlling the field from a distance.

Baxter and Chua (2008) take Bourdieuian analysis in accounting to a different domain when they take up Bourdieu's practice theory, especially the notion of habitus, to examine how one enacts being a chief financial officer (CFO), using a case study of a CFO in a large Australian organisation. 
Although they tend to neglect the dialectics of his position and his notion of embodied capital with wider relations of power, their analysis demonstrates the CFO's day-to-day engagement with his position and how his "self-professed high profile", as a sort of cultural capital, enabled him to position himself as CFO. In an interesting attempt to attribute the notion of habitus to an organisational entity, Free and Macintosh (2009) explain the demise of Enron though the evolution of its system of habitus over two distinct eras of leadership. Their analysis not only concentrates on how corporate leaders enact themselves in their positions through their cultural capital and habitus but also how such enactment is implicated in the corporate control structures and administrative practices, as well as in the games that field incumbents play against both each other and the control structures that are meant to govern their behaviour.

Business planning and budgeting have been the focus of two other studies. Oakes et al. (1998) draw on Bourdieu's concepts of field, capital and pedagogical practice to analyse business planning in the provincial museums and cultural heritage sites of Alberta, Canada. They show how such business planning, as a mechanism of control and a form of symbolic violence, works subtly through language and the construction and use of knowledge. In an attempt to synthesise grounded theory (Strauss and Corbin, 1990) and Bourdieu's concept of habitus, Goddard (2004) examines the relationship between the budget process, accountability, trust and power in local government in the UK. Habitus, here, can explain how perceptions of accountability are constructed and how they influence budget practices.

A recent paper by Hamilton and Ó hÓgartaigh (2009) comes rather closer to the way I intend to deploy Bourdieu in this paper. Their attention is on how accounting doctrines, especially the notion of true and fair view (TFV), become what they are: systems of symbolic violence that maintain and reinforce the institutionalised hierarchy of the accounting field. Together with certain (implicit) notions of symbolic systems and violence, they draw on Bourdieu's conception of habitus to explore how professional rites and rituals of "native virtuosos" who have a "feel for the game" produce "legitimate language" of accounting and how that language in turn reproduces structural properties of the field within which such rites, rituals and agential bodies that perform those rituals are situated. This is akin to my argument in this paper that calculative templates and procedures constitute a field-specific logic and they are the symbolic means through which structural properties of the social systems are cognised, communicated, reproduced and transformed into a set of practical dispositions that orient day-to-day work practices, domination and resistance.

Most of the prior literature is subject to a common criticism that it failed to incorporate all three of Bourdieu's master concepts - habitus, capital and field - into a single study (see Free and Macintosh, 2009; Swartz, 2008). As Free and Macintosh (2009) argue, Bourdieu (1998, p. 85) identifies all three concepts as indispensable, and there is a danger of missing his 'relational approach' when those concepts are appropriated piecemeal. As a result, much of their explanatory power is lost and the richness of a full-blown analysis is underachieved (Free and Macintosh, 2009, p. 4). That said, as Emirbayer and Johnson (2008) argue, in this kind of analysis the dynamic properties of the theory and the relation between the concepts is lost. However, this literature need not be demeaned simply as a result of its violation of the relational tenants of Bourdieu's theory because, as Vaughan (2008) argues, excising a concept and examining it in different social settings has contributed to our body of knowledge on accounting and control.

Even though a theory by definition requires the interdependence of parts to formulate an explanation, as Vaughan (2008, p. 67) argues, a concept becomes separated from its whole mainly due to the "scholar preference", which is a conditioned outcome of the competition among 
alternative theoretical frameworks, the complexity of the theory in question, the researcher's specialisation and data availability. Thus,

It is not that organizational sociologists have failed to grasp the relational aspects of Bourdieu's theory. One or all - competing paradigms, theory complexity, and specialization and data availability - can be obstacles to incorporating a full theory into an empirical analysis because any or all of the three may prevent us from seeing the relevance of the whole, even as these same factors may enable us to see the relevance of one or more of the theory's parts (Vaughan, 2008, p. 67).

With regard to this paper, I was fortunate to gain deep ethnographic access to a particular field that offered the chance to incorporate, inter alia, Bourdieu's key concepts - field, capital and habitus - in a relational manner to demonstrate how they explain collectively the presence and absence of calculative and control practices. The analysis, while fundamentally grounded on ethnographic data, uses Bourdieu's 'political economy of symbolic forms and symbolic power', where emphasis is placed on the role of symbolic forms and processes in the reproduction of social inequalities. This is not the only feature that distinguishes this paper from other accounting and control research that draws on Bourdieu. The paper also differs in terms of the cultural political specificities of the ethnographic field: an ethnography of a pre-capitalistic mode of production that survives in a lessdeveloped country, providing an opportunity to contribute to the stream of accounting literature that deals with the 'absence of accounting' (Choudhury, 1988; Jacobs and Kemp, 2002).

\section{Political economy of symbolic forms and power}

Bourdieu's work can be taken, he believes (Bourdieu, 1989, p. 14), as "constructivist structuralism" or "structuralist constructivism", within which he tries to reconcile two aspects of social genesis; on the one hand, the schemes of perception, thought, and action that are constitutive of what he calls habitus and, on the other, the social structures of what he terms fields and classes/groups. Thus, through a reconceptualisation of the relations between the symbolic (subjective) and material (objective) dimensions of social life, he develops a political economy of symbolic forms and power that attempts to provide a theoretical and empirical analysis of how social inequalities are reproduced through practices of symbolic power and symbolic violence. At the centre of this theoretical construction lies the role of symbolic systems (which include arts, science, religion and language) as structuring structures that mediate practices by connecting individuals and groups to institutionalised hierarchies (see Swartz, 1997, p. 1). Systems of calculations are such symbolic systems, which mediate the effects of wider power structures to produce various forms of calculative and control practices.

For Bourdieu, the socialised body does not stand in opposition to society; it is one of its forms of existence. Social reality exists both inside and outside social actors, in both our cognitive structures and objective social structures, manifested by the material existence of things outside our cognitive structures. Thus, in our sociological analyses, the individual and society should be constructed relationally, as if they are two dimensions of the same social reality (see Swartz, 1997, p. 96). Bourdieu constructs this inseparable connection between the socialised body and the structural logics of the social space through a set of conceptual devices: some of which are more related to the socialised body while others are more a means of understanding the structural logic of the "field". There is also another set that is related to social processes and the relations through which one class/group of social actors would exercise symbolic power over others. The "practical logic" (Bourdieu, 1990b) of calculative and control practices needs to be understood within this relational dynamic between the socialised body and the structural logic of the field. Thus, the attempt here is to grasp the totality of his theoretical construct and to locate the 'logic of calculative practices' 
therein. Fig. 1 provides an outline for my conceptualisation of Bourdieu's political economy of symbolic forms and symbolic power.

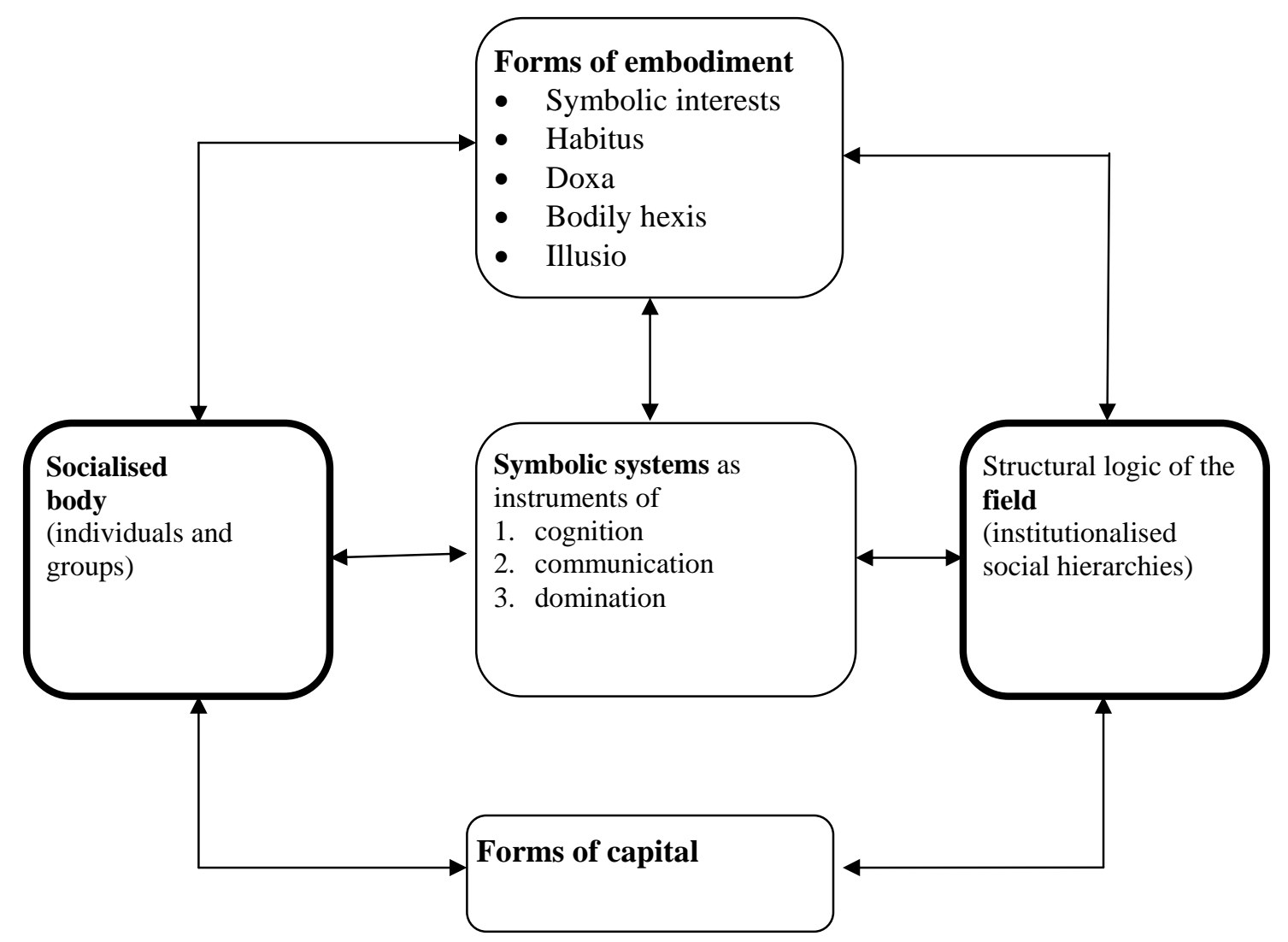

Fig. 1. Bourdieu's political economy of symbolic forms and power.

In Bourdieu's political economy, 'field' is the structure of a conflictual social setting or 'field of struggle', in the context of which his other concepts are to be located and understood. A field is meant to encompass a structural logic according to which specific types of capital are competing against each other for a stake in the game; every field has its own self-defining stakes and interests, which are irreducible to the stakes and interests specific to other fields (Bourdieu, 1995, p. 72). As such, a field becomes a structured space of dominant and subordinate positions based on types and amounts of capital (Swartz, 1997, p. 123). The structural logic of a field imposes on actors specific forms of struggle, which they internalise through various forms of embodiment; they then mobilise such embodied or objectified properties as a form of capital to pursue their specific interests in the field as well as to resist the dominating influences stemming from the other forms of capital in the field.

\subsection{Forms of embodiment}

Reading through Fig. 1, the set of concepts in Box A shows the different ways in which individuals and groups embody the structural logic of the field. They are the mode of reproducing the objective social structures within the cognitive schemata of the socialised body, and the media through which the socialised body is facilitated to produce actions according to the logic of the field. However, such 
actions are not mechanical responses to external determining structures. Instead, symbolic interests, habitus, and other forms of the embodiment of the cultural and social legacies of the past filter and shape individual and collective responses to the present and future (see Swartz, 1997, p. 69). In other words, structural 'distinctions' manifested by the institutionalised hierarchies are embodied distinctively by individuals belonging to different social categories in order to reproduce different mindsets and behaviours in distinctive social situations/fields.

As Swartz (1997, pp. 66-73) also argues, Bourdieu posits that all actions are patterned and interest-oriented at a tacit, prereflective level of awareness that occurs over time. However, Bourdieu's concept of symbolic interests should not be read as an independent principle of action within his conceptual framework. Instead, material and symbolic interests are defined by an actor's (or group of actors) position within institutionalised hierarchies. They are the embodied dispositions that operate at a tacit, taken-for-granted level (Swartz, 1997, p. 71). Thus, "interest is a historical arbitrary, a historical construction that can be known only through historical analysis, ex post, through empirical observation" (Wacquant, 1989, p. 42). Nevertheless, actors participate in social interactions and pursue symbolic and material interests as strategists who respond over time to a mass of constraints and opportunities that they grasp through "practical knowledge" or a "sense of practice" (Swartz, 1997, pp. 99-100). In this sense, actors "are strategic improvisers who respond dispositionally to the opportunities and constraints offered by various situations". And the "choices stem from practical dispositions that incorporate ambiguities and uncertainties that emerge from acting through time and space" (Swartz, 1997, p. 100).

When the structural logic of the field is internalised as habitus and bodily hexis, "the point of view of those who dominate by dominating the ... [field] and who have constituted their point of view as universal by constituting the ... [field]" (Bourdieu, 1998, p. 57), is also embodied. This dominant vision, often manifested as the orthodoxy of a particular field, is the doxa. Internalising the doxic disposition means submission to the logic of symbolic domination in the field. By the same token, social agents who compete for their material and symbolic interests in a particular field also ingrain the illusio that leads one to engage in the central game of the field: they ingrain the idea that the game is worth playing, invest in it, and are taken in by it (see Bourdieu and Wacquant, 1992, pp. 98, $115,173)$.

\subsection{Forms of capital}

For Bourdieu (1986, p. 241), following Marx, the social world consists of accumulated history; capital is accumulated labour in its material or embodied forms. When appropriated on an exclusive basis by agents, capital enables them to appropriate social energy in the form of reified or living labour. As such, individuals and groups draw upon various forms of capital in order to maintain or enhance their relative positions in the social order and, in that struggle, capital becomes a "social relation of power" (Swartz, 1997, p. 73). Capital, therefore, represents power "over the mechanisms which tend to ensure the production of a particular category of goods and thus over a set of revenues and profits" (Bourdieu, 1991b). However, unlike Marx, Bourdieu extends the idea of capital to all forms of power: material, cultural, social or symbolic. Thus, for Bourdieu, capital can take different forms: economic, cultural and social capital.

While economic capital is institutionalised in the form of property rights, cultural and social capital take somewhat subjective and complex forms. For example, cultural capital can exist in three different states: the embodied state (i.e. in the form of long-lasting dispositions of the mind and body); the objectified state of tangible cultural products, such as uniforms and other dress codes, pictures, books, machines; and the institutionalised state, such as accreditations and qualifications (Bourdieu, 1986). Similarly, social capital represents durable networks of institutionalised 
relationships of mutual acquaintances and recognition, which provides individual social actors with a "credential" that helps them to exploit and dominate the social relationships in a particular field of power (Bourdieu, 1986, pp. 248-49). Importantly, in Bourdieu's sociology, capital is not only a force inscribed in subjective and objective structures but also the principle underlying the immanent regularities of the particular field. Accordingly, habitus, bodily hexis, and other forms of embodiment of the structural properties of the field by individual social actors can become, in the long run, embodied forms of capital which, in turn, can be mobilised to accumulate other forms of capital (especially economic capital) by dominating the field and appropriating its surplus value through symbolic means. This symbolic form of dominating and exploiting the social relations in a field of power is known as symbolic violence, which takes place through symbolic systems and instruments.

\subsection{Symbolic systems}

Symbolic violence is the subtle domination of one class of social actors by another through imposing the means for comprehending and adapting to the social world by representing economic and political power in disguised, taken-for-granted forms. This is realised through symbolic systems that exercise their power through the complicity of those who are subject to it (Bourdieu, 1991b). The arts, science, religion and, indeed, all symbolic systems - including calculative systems - are not only instruments of communication and the construction of reality but also the means through which social hierarchies and inequalities are established and reproduced. They constitute the social mechanisms that connect individual social actors to institutionalised hierarchies.

According to Bourdieu (1979), symbolic systems simultaneously perform three interrelated but distinct functions: cognition (symbolic systems as structuring structures), communication (symbolic systems as structured structures), and domination (symbolic systems as instruments of domination). In the first two functions (cognition and communication as structuring and structured structures), symbolic systems become instruments of knowledge and communication that exert a symbolic power: a power to construct reality as a gnoseological order, and social solidarity resting on shared symbolic systems and their resultant gnoseological order. As such, they make possible a consensus on the sense of the social world (Bourdieu, 1979, p. 79). Thus, as a gnoseological order, the structural logic of a particular field is cognised and communicated through symbolic systems. Various calculative systems can thus become symbolic instruments of cognition and communication; they become systems that materialise the deep social structures of a particular field.

Relations of communication are always, inseparably, relations of power (Bourdieu, 1979, p. 80) and, in that sense, symbolic systems also function as instruments of domination, or as instruments that legitimate domination. The dominant factions of a particular field, whose power is often based on economic and political capital, seek to legitimate their domination through various symbolic instruments, such as discourses and writings, which reproduces traditions of domination as historically legitimate, or transforms such traditions into new ones, as others become outdated over time. That said, forms of knowledge and relations of communication are inherently enmeshed with relations of power because they are the relations within which the dominating structures are reproduced. Symbolic systems, as structuring and structured systems, combine their cognitive and communicative functions with that of domination.

Calculative systems are also structured and structuring systems. They are structured by their historical evolution as tools of institutionalised practices and also as embodied dispositions of the social agents who mobilise, and are subject to, such calculative practices. As such they bear the structural conditions of the field in which they evolved and operate. They are structuring because 
they orient and shape the actions and practices of social agents and institutions. They are structures in that they hold a set of systematically interrelated templates, procedures and mechanics, according to which day-to-day work and other social practices are cognised, communicated and regulated. Calculative systems not only perform cognitive and communicative functions but also serve as instruments of domination. They, as symbolic systems, "provide integration for dominant groups, distinctions and hierarchies for ranking groups, and legitimation of social ranking by encouraging the dominated to accept the existing hierarchies of social distinction. They, therefore, fulfil a political function" (Swartz, 1997, p. 83, see also Bourdieu, 1979). After all, calculative templates, procedures and mechanics are instruments through which dominating forms of capital appropriate the surplus value of the field. In the empirical sections, after the methodology, I will show how a particular calculative system, as a symbolic system, performs these three functions and thereby reproduces the dominating structures of the field of Sri Lankan gem mining.

\section{Research methods and site}

Methodology is neither a technique of data collection nor a specific branch of theory, but the framework that provides the link between technique and theory (Burawoy, 1991). Techniques help identify appearances as events, interactions, practices and relationships. However, reality is more than mere appearances may suggest. Its essence lies in the deep social structures, which should be theoretically abstracted. The task of sociological research, according to Bourdieu (Bourdieu and Wacquant, 1992, p. 7) is "to uncover the most profoundly buried structures ... as well as the mechanisms which tend to ensure their reproduction or their transformation". However, Bourdieu also writes that such structures are peculiar in that they lead a "double life" (Bourdieu and Wacquant, 1992, p. 7): they exist twice. On the one hand, they exist in the "objectivity of the first order" that is constituted by the distribution of capital, or the means of appropriation of surplus values. On the other, they are in the "objectivity of the second order", constituted by the systems of classification or the mental and bodily schemata (habitus, bodily hexis, etc.) that function as symbolic templates for the practical activities of social agents. As such, a field-based social inquiry needs a dialectic reading of this double life of field structure and demands a set of methods that provide the researcher with broad access to the field - broad enough to penetrate the mental and bodily schemata. Thus, with the understanding that day-to-day social practices are the interactive bottom-line of control, resistance, hegemony and calculations, meaningful access matters a lot. This is why ethnography has been one of the most popular research methods in field-based sociological inquiries (Wacquant, 2003, 2004a, 2004b). Ethnographic research generally involves intensive, face-to-face participant observation in a natural setting over a reasonable period to allow the researcher to produce meaningful narratives of the actions, practices and ideological frameworks of a particular social system (Willis, 2000). This research adopts such an ethnographic approach with a broad access not only to the structural properties of the 'field' of gem mining in Sri Lanka but also to the particular forms of embodiment through which structural properties of the field are internalised by its agents. Very similar to Bourdieu's Algerian ethnographies, the ethnographic setting was my home town ${ }^{1}$ where I spent first half of my life, and where my extended family and village friends still live. They have various stakes in gem mining in the area, ranging from labouring in the gem pits to wealthy gem merchants. I had even worked a couple of years as a gem pit worker, though not during the period of formal fieldwork ${ }^{2}$. As in the case of Wacquant $(2004 a, 2004 b)$

1 Rakwana, Sri Lanka. This small town is located in the district of Rathnapura (literally meaning "city of gems") and is famous for its blue-sapphire. The town is surrounded by quite a few gem pits and its main street largely populated by gem merchants.

2 This was during the period from 1986 to 1988, after my A/L but before entering the university on a government scholarship. All public universities in Sri Lanka were closed from 1986 to 1990 due to a civil war in the country. Thus there was a period of discontinuity in my "life progress" where I deployed my body in rather "off-line" and temporary occupations. 
"Body and Soul", this carnal experience of being a pit worker has, no doubt, helped me to "clasp and restitute the carnal dimensions of existence" (Wacquant, 2004a, 2004b, p. vii) as a pit worker. However, I would not claim that the current piece of research is a result of a carnal sociology: "a sociology not only of the body, in the sense of object, but also from the body, that is, deploying the body as a tool of inquiry and vector of knowledge" (Wacquant, 2004a, 2004b, p. viii, emphasis original). My deployment of body as a gem pit worker was not at all driven by such a sociological adventure but by the mere economic and social necessities of its deployment in the field, many years before the (re)engagement in the field as a researcher.

Initial data collection was achieved over a nine-month period of fieldwork during 2001-02, with two subsequent short visits to the field in 2005 and 2007. Data collection was mainly undertaken via direct participant observation and 'engagement' in various social settings, including occasional gem pit operations, gem auctions, out-of-hours gatherings and social occasions. Every-day work activities and social relations were closely observed and transformed into field notes around calculative and control practices, and ideologies were embedded in such observations. Continuous but distant contact is maintained with the field actors through 'friendly and related' telephone conversations; such conversations helped a lot in the refinement and gap-filling of field notes taken at the time of fieldwork. At the writing-up stage, the field-based ethnography was transformed into an "analytic ethnography" (Snow et al., 2003) by entwining the field-data with a theory that helps make 'theoretical sense' of the data. The analytical focus was mainly on an understanding of the presence and absence of particular control practices and the field-specific logic of calculative practices.

Ethnographic data can be understood better when they are placed vis-à-vis the peculiar characteristics of the field. Hence more elaboration of the site is needed here. Sri Lanka is a postcolonial developing economy with a population of 20 million and a per capita GDP of US\$2,053 (Central Bank of Sri Lanka, 2009). It had been a colony of British Empire for more than 150 years until 1948 when it became an independent country. According to Sri Lankan Central Bank statistics, its current economic composition is dominated by garment and other textile products (around $40 \%$ of total exports during the last decade or so) and plantation crops (around 20\% of total exports). Gem mining contributes just less than $2 \%$ of the nation's exports.

Gem mining and trading in the country are mainly concentrated in a few towns and villages in the Rathnapura District. This high geographical concentration of the industry means that its presence in the day-to-day lives of people in these towns and villages is much more significant than what the centralised statistics suggest. A mere visit to any of these gem trading towns would reveal how "gem money" (as the accumulated wealth through gem mining and trading is commonly known in the area) is present everywhere in the town: in the sign-boards of the shops ${ }^{3}$, sponsorship banners of various social events by wealthy gem merchants, large houses of wealthy gem merchants, and also the physical presence of gem merchants and traders in their "symbolic" clothes (typically expensive batik sarongs, white shirts, gold watches, gold necklaces, and leather slippers). The

3 Quite a few gem-shops can be found in every major town in the Rathnapura district. They belong to wealthy gem merchants and are normally multi-story buildings. However, there are no any gems or anything else to sell in there but they are so called "buying centres" where the owner merchant and his associates just spend the day waiting for gems to arrive. There is no any special equipment or machinery for checking or processing of gems here either. Inspection of a gem for its quality is done through the bear eye only with the help of a light of battery powered pentorch, which gem merchants would normally carry wherever he goes. Hence, these gem-shops (with a huge sign-board with the name of gem merchant) is rather a symbolic form of capital to express the relative wealth of the merchant and his ability to buy a gem of any value. 
presence of "gem money" can also be seen in the local political processes, especially in the parliamentary and the Provincial Council Elections wealthy gem merchant either as candidates or as financial supporters of other leading candidates. In essence, "gem money" has been a powerful force in the economic, social and political lives of people in these gem towns and villages.

Concentrating on the Rakwana town and nearby villages, where I did my fieldwork, there were six "gem shops" (i.e. gem buying centres) in the town and there were four more wealthy gem merchants operating in their houses without a separate gem shop in the town. There were around 20 gem mines at the vicinity of the town. In addition to their involvement in gem mining and trading, some of these gem merchants have textile and hardware shops in the town. They have also invested in small and medium scale tea holdings. Most importantly, they lavishly invest in various social activities and patronage politics to sustain the symbolic presence of "gem money". Local politicians and leading government officers in the province would not visit the town without visiting some of these gem merchants with whom they maintain long-term allegiances. It is very hard to see a gem merchant without his set of "goloyos" (i.e. literally meaning apprentice: a set of young/emerging merchants making their living by doing so-called "miscellaneous work", which also include selling "eerattu" (law value gems) in the secondary market on behalf the merchant). In all means gem merchants are significant economic, political and social actors in the area and you wouldn't see any big social events without a gem merchant being invited as a "chief guest" or the "guest of honour": they sit in the same raw of chairs with the politicians and other leading government officers in the area. They are the linking pins between the field of gem mining and various other economic and political fields in the area.

Economic inequality in the gem mining towns and villages is apparently very high. While there are very rich gem merchants, there is also a large number of young unemployed. As school leavers (with no chance of entering into higher education due to very limited spaces in public universities), these unemployed youths make up the major supply of labour to gem mines. Given the gambling nature of gem-mining and the traditions of appropriating the surplus value (discussed later), only a very few would continue to stay for long in gem mining as workers: most would have a short career as a worker and move out as soon as they find an opportunity to do so. Once they accumulate an initial capital to do so, many would try their luck in gem trading instead of gem mining. For many "gem mining is the fool's luck"; something worth enough to try if you "have no options but to toil the muddy soil down the pit" or you "have enough to risk a bit with no worries". A gem pit therefore brings together people at these two extremes of capital endowment.

Investment in a gem mine has always been a collective venture, with the contribution of various 'forms of capital' (such as lands, timber, tools, water engine, and so on. This is more elaborated in forthcoming sections) by various actors in the town/village. Nevertheless, gem merchants would always have an upper hand in the final appropriation of income from a gem mine, especially due to their contribution of multiple forms of capital and also due to their engagement in the gem trading (discussed later).

\section{The gem pit: a ritualised labour process}

Contrary to the structural organisation of the mining industry in the west (see Boyns and Edwards, 1996; De Beelde, 2000; Vent and Milne, 1997, 2000), gem mining in Sri Lanka has never been organised through 'corporate entities' of any sort. They have always been communal enterprises organised and coordinated via the patronage of social relations and social rituals in villages. However, as Choudhury (1988) argues, the absence of modern corporate apparatuses does not nullify the possibilities of studying accounting. Instead, it contains information on the particular contexts within which modern organisational apparatuses, including modern forms of accounting, 
are not socially assumed to be necessary and have never become institutionalised/embodied practices within the social contexts of production. So, studying what is there, instead of modern forms of accounting, will give us the opportunity to reveal not only the other forms of accounting and control but also the structural conditions that facilitate or hinder the evolution of modern forms of accounting.

Structural conditions, on the other hand, are not givens and would not necessarily dictate the forms of coordinating economic activities. Every field of production, at a certain phase of its temporal and spatial evolution, has a particular physical and technological nature beside its cultural grammar, and that particular nature would have a significant say in articulating how various forms of capital are mobilised and how various modes of coordination and control are deployed for its governance. Gem mining has a particular physical nature that renders it 'a game of gambling' resulting in a particular form of structuring the field to diversify the stakes and the risk of the game among a spectrum of social actors.

The physical processes of gem mining involve digging a deep pit, approximately $12 \times 12$, until a particular layer of soil is found, called 'illama', an alluvial layer of coarse, pebbly material, which contains traces of clay and fine sand where gemstones are geologically deposited. Contrary to the gold or coal mines in other parts of the world, Sri Lankan gem mines are not land intensive. A single gem mine would need a maximum of 10-15 perches ${ }^{5}$ of land, which are mostly found in a middle of a paddy field, and co-exist with paddy farming. In wet and muddy surroundings, this pit often goes as deep as 50 yards or so, with carefully constructed walls around it, and wooden scaffolding to prevent the walls of the pit from collapsing inwards. Once this particular layer of soil has been reached, digging continues, making horizontal tunnels parallel with that special layer of soil "until the flame of the candle light gets weaker" (customarily, no electric or battery-powered lighting is used; the weakening flames of candles are used as a measurement of low oxygen levels down the pit). The purpose of digging and tunnelling is to collect as much 'illama' as possible, because it is the quantity ${ }^{6}$ of this special soil that maximises the stakes of the gamble - finding a valuable cache of gems. Once the illama has been taken to the surface, it is piled in a secure place near the pit until it can be washed in front of everyone with a stake in the gem pit. Illama is washed in a large circular wicker basket by immersing in water and rotating it. This enables the light, ordinary pebbles and sediment to escape, leaving the heavier pebbles behind. Then the basket is held against the sunlight and carefully scanned for gemstones.

As "a set of historical relations 'deposited' within individual bodies in the form of mental and corporeal schemata of perception, appreciation, and action" (Bourdieu and Wacquant, 1992, p. 16), relations in production are ritualistic and structured by a set of habitus and bodily hexis (see Bourdieu and Wacquant, 1992, pp. 167-8). Habitus is a practical disposition, which explains why social practices of certain classes of actors are characterised by regularities. Habitus is a property of social agents and it is "that which one has acquired, but which has become durably incorporated in the body in the form of more or less permanent dispositions" (Bourdieu, 1995, p. 86). It is a "system of structured, structuring disposition" (Bourdieu, 1990b, p. 52) and the term disposition is the key

\footnotetext{
4 There are three modes of gem mining in Sri Lanka: deep pit mining (gaburu pathal), shallow pit mining (goda pathal) and river-bed pulling (adum pathal). Among these, deep pit mining is the most popular and largest in scale in terms of operations and capital requirements. This paper mainly concentrates on deep pit mining.

5 'Perch' is the conventional measurement unit of land in the field. A squire perch $=25.29$ square meters.

6 Typically, as a gem pit worker explained, "if we are lucky enough, we get two 'piles' (up to the height of a grown man and a diameter of around 10 feet or so) of illama.When we washed them all, we would get a handful of 'stones' [gems]. If we are so lucky, they can all be nill [blue sapphire] or wairodi [cat's eye], or they can just be all thorammali [semiprecious gems with little value in the market]".
} 
to this definition, since it suggests two essential components of the concept of habitus: structure and propensity (see Swartz, 1997, p. 103). On the one hand, habitus becomes the dispositional means through which social actors, through their socialisation experiences, internalise external structures. Broad structural parameters and the boundaries of what is possible or unlikely for a particular group of social actors in the institutionalised hierarchy are internalised and embedded as dispositions through socialisation. In that sense, habitus sets structural limits for actions (Swartz, 1997, p. 103) and leads individuals to a "kind of immediate submission to order". Habitus, thus, legitimates the material and symbolic inequalities by providing a practical and taken-for-granted acceptance of the fundamental conditions of existence (Swartz, 1997, p. 105). On the other hand, habitus also implies that actors encounter and act upon the present in terms of previous experiences that they have embodied through socialisation. As such, habitus becomes a structuring structure, that is, as a principle of the generating and structuring of practices, it generates strategies that can be objectively consistent with the material and symbolic interests of the social agents without having been expressly designed to that end (Free and Macintosh, 2009, p. 11).

Certainly, there are calculative and control implications of such work habitus, as they offer a cultural grammar for structuring day-to-day work practices and negate the necessity for 'other' forms of accounting, planning and control. For example, a typical answer to the question of how many workers would be ideal for a pit was "six workers: in rotation, two at the bottom of the pit, two at the top to pull the rope, and another two to move soil on and off the pit... most importantly, no one should ever be down in the pit alone". Such habitus "is a product of history which produces individual and collective practices. It ensures the active presence of past experience which tend to guarantee the 'correctness' of practice, and their constancy over time, more reliably than all formal rules and explicit norms" (Harker and May, 1993, p. 174). However, a habitus is not a rigid rule or social code that determines the actions. Instead, it sets the boundaries within which agents exercise a relative freedom in adopting and adapting practices according to the "feel for the game", as Bourdieu calls it, which is "what enables an infinite number of 'moves' to be made, adapted to the infinite number of possible situations which no rule, however complex, can foresee" (Bourdieu, 1990a, p. 9). They do not, in a practical sense, necessarily determine actions but orient them. As Bourdieu argues,

modes of behaviour created by the habitus do not have the fine regularity of the modes of behaviour deducted from a legislative principle: the habitus goes hand in glove with vagueness and indeterminacy (Bourdieu, 1990a, p. 77).

In our empirical context, for example, the habitus of six workers for a pit, though recursively referred to in conversations on planning the pit work, is vague and indeterminate. The actual number working on a particular pit, and how they organise the work between them, differs to reflect social conditions and the relations among the people in the working party. As one pit organiser put it:

You can work a pit with six workers, and that would be the ideal. If folks working in the pit need more than six in the gang, it is up to them. Sometimes, they of course have more than six in their gang. When one of their friends or relatives wants to join them they can't simply say no; they would be happy to get him to work with them. It affects their income not mine or anybody else contributing to the pit [because of the particular mechanism of appropriating the stake: see below]. Sometimes, they are even less than six and anyhow mange the work but, for their own safety, they should always make sure that no one, however good and experienced that one would be, should ever be down in the pit on his own. 
This vagueness and indeterminacy of habitus facilitates the agency of social actors creating their own social space relatively free from external pressures and controls. The result is less alienation within the relations in production and more freedom to exercise the collective will of the labour force. In that sense, habituses become something collective; something cultural enough to penetrate the collective conscience that structures their dispositions on technicalities and the social relationships at work. For example, the following quotation from a group of workers exemplifies not only this relative freedom and the collective agency of the labour force to determine its own conditions but also how the "feel for the game" orients their actions and strategies.

Many pits go with six, but we got eight here in our pit. We were eight for so long now and that works very well for us. However, KP will leave the pit very soon, because he is going to get back his job in the police [he had been suspended on an alleged case of bribery]. Then, we may continue with seven or someone else may join us; who knows! ... We learn from others what to do and how to do when we start work in a pit as young kids. After that, nobody would tell us what to do and how to do; everybody knows what they need to do, and how to do them. Don't they? If you keep on asking others what to do, you become an idiot and they will take you for a joke.... Everyday work is not the same. If the pit is too full [of water] or it is raining, no use of running the water-pump. You just waste diesel. We can't do any pit work, and we would prepare timber for the next day's work or we would just sharpen the tools and clean the water engine. You can't just spend the day doing nothing. Can you? ... What we did few months ago [i.e., in the early phase of the pit work] were not what we are doing now [at the deep digging and tunnelling stage]. We hope, with the blessing of the god, we will be washing a big load of illama before 'new year' [the festival season] ... Every hour or so we would take a break for a cup of tea and a smoke, and change our positions. ... When a good match [cricket] is on the TV, we all would be watching it and no work at all. Who would bother to work then? [Laughter].

Embodimentof the field's structural logic takes a physical or bodily form as well as amental one. Bourdieu terms this bodily dimension of embodiment "bodily hexis". It is the bodily manifestation of a permanent disposition - a durable way of undertaking certain physical acts such as using a tool, standing, walking, speaking and, thereby, feeling and thinking (Bourdieu, 1990b, pp. 69-70). Similar to Foucault's "disciplinary principles", especially the maneuver (Foucault, 1979; Macintosh, 1994, p. 224), bodily hexis is amode of disciplining the body to realise the structural logic of the field: by adopting a particular set of bodily hexis, classes of actors constitute themselves as a set of disciplined incumbents in the field.

As observed, the labour process in the pit was neither regimented nor subject to direct supervision by anyone external to the labour gang. The way work is organised and carried out is left to the workers, but ritualised and structured by an explicit set of habitus and bodily hexis, such as: "Where to put the logs on the pit wall is always decided by basunnah ${ }^{7}$ and everybody should act on

\footnotetext{
The term basunnah (Sinhalese) refers to a person with special skills in carpentry and masonry. In the context of gem mining this involves the special skills of wall building with wooden logs and plants, a skill that would ultimately determine the safety and life chances of all mine workers, and a skill that one would accumulate only over many years of experience in mining. Thus, this has always been a cultural capital that warrants a higher stake in the game (at least more than other workers, see below). One would become a basunnah through accumulating this stock of cultural capital: working in gem pits for so long that guarantee others' acceptance of him as having the bodily hexis and habitus of a basunnah. For some, however, this is nothing else but his "bad karma (pow) ... too much of him making others richer but him yet toiling the muddy soil down the pit".
} 
his 'shout' [a form of giving instructions loudly so that everybody in and beyond the pit can hear it and synchronise their individual acts] ... young ones, until they catch the art of using it [i.e. according to the terminology of Bourdieu, this means until they accumulate a particular stock of cultural capital], should use the vaya [a very sharp tool used to shape wooden logs, which, if it misses its mark, can cause severe leg injuries] only with the help of an experienced elder." Elderly workers have gained an "individual trace of an entire collective history" (Bourdieu, 1990a, p. 91), have learnt a particular set of bodily hexis and habitus that spell out the 'correct' ways of using a particular tool or doing a particular job. They pass that cultural capital to the younger ones, on the one hand, as one of their social responsibilities and, on the other, in gratitude for the subordination and obedience of the younger members of the group. For younger workers, learning such bodily hexis and habitus constitutes exposure to the mockery of making mistakes, the punitive element of the learning process at work, and also the joy of being able to do the "hard work of men", which promulgates the "possession of a strong body". Through day-to-day exposure, with their own ways of reacting and responding to those punitive elements of social learning, individuals trace an entire collective history of working in a gem mine; thus, habitus and bodily hexis pass on to individuals as a structured and structuring structure of work.

The social composition of the gang, especially the age structure and kinship relations within it, operates as the disciplining structure at work. Assessment of the speed and the quality of the work of an individual is naturally built into the collective work process, in that an individual's sluggishness would slow down the whole process and he would soon gain attention for "correction through mockery". That said, structuring of work as a synchronised action between two or more interdependent work elements (for example, throwing and catching, pulling and pushing, holding and hammering) has operated as a physical mode of coordination as well as control. It is common to see conflicts between the workers in the gang. They often arise from "making too much mockery" of a weak worker (often young and new to mining). However, such conflicts tend to be temporary and easily resolved by the jurisdiction of an elderly worker whose presence in the gang acts as a referee. Such mockery and conflicts constitute the natural tone (and the joy) of work interactions. They provide a necessary 'social' element of the work and transform the day-to-day interactions into a sort of social game. At the micro level of social interactions in the gem pit, individuals, depending upon their individual character and the position they hold within the workgroup, play this game for the small stake of winning and losing a particular act of mockery, or just for the selfsatisfying demonstration of their 'bodily ability' to perform a particularly difficult job better (or not worse) than others. In essence, social relations at work have been structured into game playing, the mastering of which entails the embodiment of a cultural capital within individual bodies, at least to escape the punitive elements of learning the trade and, at best, to enhance their chance of upward mobility within the social hierarchy. Playing the day-to-day game of social relations at work not only integrates individual workers into the collective disposition of work but also structures the relations of accountability and control, where surrendering to the seniority and elderly kinship positions has always been a doxic attitude.

Within this system of production, the documentation of worker attendance, resource consumption or any other work related information was virtually absent. Detailed calculations of resource requirements, either for planning or control purposes, are deemed to be unnecessary, and calculations of costs or profits are not carried out. Detailed calculations, assessments and documentation have not been part of the "practical logic" of the existing set of habitus, doxa and bodily hexis that structure work practices. The need for quantifications and qualitative assessments of resource requirements (for example, wooden logs and fuel for the water pump) for 'rationalised planning and control' (as assumed in modern enterprises in western capitalism) does not arise because of the particular social contract to which various forms of capital in the field enter (see 
below). Or, in other words, formal record keeping and the control apparatuses of modernity have not yet penetrated practices in the field of gem mining. Instead, a set of idiosyncratic traditions are in place, which structure the day-to-day practices of work and control.

However, the absence of accounting and the relative freedom of labour from external controls, especially of other dominant forms of capital, are not fully explained either by the internal social organisation of labour itself (i.e. relations in production) nor by the presence of a set of habitus and bodily hexis particular to the field of gem mining. The logic of absence of 'formal' control and accounting also lies in the particular way that capital is formed and arranged within the field (i.e. relations of production). In the next section, in the light of a set of material practices associated with valorisation, I will discuss the field-specific logic of capital formation and its implications for calculative and control practices.

\section{The auction: calculations and logics of appropriation}

Social systems of production are reproduced by field logics of appropriation that structure the field capital to constitute structures of inequality, domination, symbolic power and symbolic violence. According to Bourdieu (1990a), a field can be understood as a competitive game or "field of struggles" in which social agents strategically improvise in their quest to maximize their positions articulated by the relative endowment of various forms of capital and the social interests attached to those varieties of capital. That said "every field, as a historical product, generates interests which is the precondition of its functioning" (p. 88). On the other hand, "the existence of a specialised and relatively autonomous field is correlative with the existence of specific stakes and interests" (p. 87). Thus, a field, as a terrain of gaming, is structured by a set of interests, stakes and investments, according to which field incumbents struggle for the maintenance or advancement of their social positions through accumulation of various forms of capital. Turning our focus to calculative practices, as a distinctive set of social practices, particular forms of calculations can become the social logics through which these field-specific interests, stakes and investment propositions are articulated as the field-specific logic of appropriations. Implicit and embedded in these calculations would then be the parameters of social space and symbolic power, which are reproduced, as the set of rules that govern the game, within practices of production and valorisation through various forms of calculations. Importantly, particular forms of calculations can become the doxic mode of explicating the "rules of the game" that determine the stake of each social actor in the field.

This logic of calculative practices is exemplified by the way that the gem pit is resourced and how sales proceeds are appropriated. Once the illama is washed and gems are found, they are sorted into different "lots" according to their types. Wrapped in white tissue paper, they are then presented in the 'pit auction', which most of the area's gem merchants attend, except a few 'big merchants'. Having carefully examined each lot of gems for type, quality (mainly purity from cracks and transparency of light) and size, each merchant puts his bid on a piece of paper (the 'auction chit'), rolls it to hide the writing, and puts it into the auction basket. Once the highest bid is revealed at the end, the labour gang is free to either accept or reject it. If they think that they can find a better price somewhere else (they will often take some 'private bids' before the auction, especially from 'big merchants' who would not normally attend such auctions because of their social status and reputation) they are able to refuse the auction price and sell the gems out of auction.

It is not the mere process and the rituals of the gem auction but the calculations embedded in the appropriation of auction proceeds that reveal not only the field logic of capital investments and accumulations but also how wider social hierarchies are reproduced through particular calculative practices at the point of production. Once the final sales proceeds of the gem pit are determined, a chart (as shown in Fig. 2, which also shows my English translations superimposed and is elaborated 
in Table 1) is prepared to show the "share" of various modes of capital that define the field of gem mining.

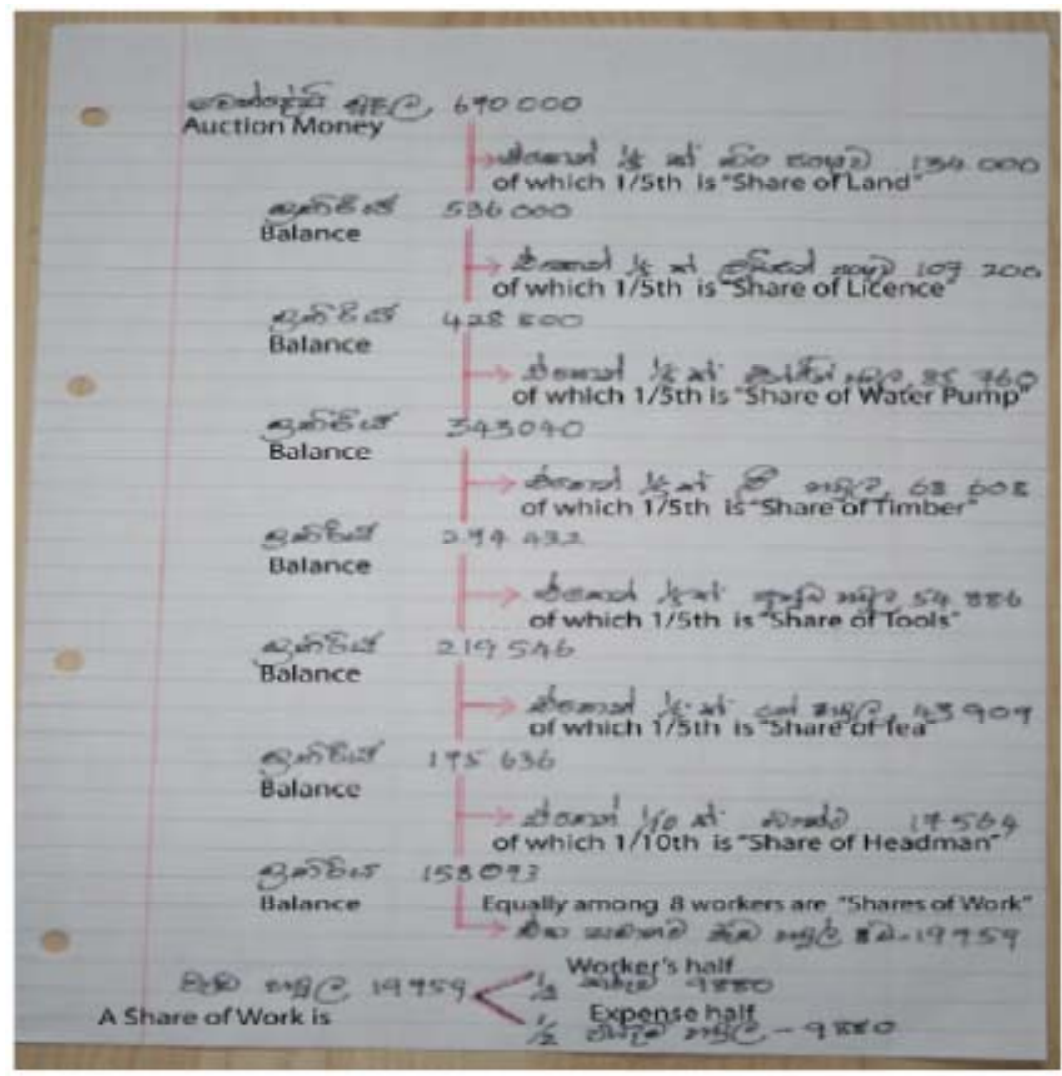

Fig. 2. The calculative logic of appropriation and social reproduction.

The calculative logic behind this chart is somewhat doxic, a product of the historical tradition of gem mining. Distribution of auction money is almost identical in all instances in the area and follows the same rank-order of different forms of capital "leaving the labourers only with smallest share". Only minor differences can be seen in some special occasions. An example of such a minor difference is where a gem pit runs without a proper government licence to do so, instead of the "share of licence", there may be "police panguwa" - the police share, which goes to the relevant police officers who then prevent the gem pit from being raided. Similarly, in one occasion, workers decided not to have tea from any other party and therefore avoided a "share of tea" being paid out. The origin of these practices of appropriation cannot be traced and dates far back beyond the memory of many elderly workers and gem merchants: "as far as I remember, this is how it was done for generations." Despite its origin and minor differences in practices, this calculative practice vividly illustrates how an underlying social hierarchy of symbolic power and symbolic violence is relationally built into a particular schema of capital, and how that social structure is reproduced within the calculative practices of valorisation through a particular calculative template. 
Table 1: Organisation of a gem pit: capital formation, social stratification and returns

\begin{tabular}{|c|c|c|}
\hline Form of capital & Return & Person contributed \\
\hline $\begin{array}{l}\text { Land: Commitment of land to the venture until it } \\
\text { is over. Land is not "sold" to the venture but just } \\
\text { "rented" Land would normally put back to its } \\
\text { ordinary use after the venture. }\end{array}$ & First $1 / 5^{\text {th }}$ of the auction money Rs. 134,000 & $\begin{array}{l}\text { Mrs K, a retired school teacher and her } \\
\text { extended family. }\end{array}$ \\
\hline $\begin{array}{l}\text { Licence: fees and expenses incurred to obtain the } \\
\text { government licence for gem mining in the given } \\
\text { plot of land. This involves a certain degree of } \\
\text { cultural and social capital as well in terms of } \\
\text { contacting and getting the patronage support of } \\
\text { relevant government officers and politicians. } \\
\text { "you need a bit of oiling and greasing to push your } \\
\text { application through, otherwise it will never pass } \\
\text { some officers desk" (a comment by a gem } \\
\text { merchant). }\end{array}$ & $\begin{array}{l}1 / 5^{\text {th }} \text { of the remainder of the auction money } \\
\text { after the share of land. } \\
\text { Rs. } 107,200\end{array}$ & $\begin{array}{l}\text { 'Mudalali' P (a gem merchant). "I got people } \\
\text { to do this for me, I just need to throw some } \\
\text { money" } \\
\text { (Mudalali is the Singhalese for a wealthy } \\
\text { merchant, also works as a word of honour). }\end{array}$ \\
\hline $\begin{array}{l}\text { Water engine and its running cost (i.e. diesel and } \\
\text { maintenance). The water engine goes back to its } \\
\text { owner after the venture and he would normally } \\
\text { continue to invest it in another venture. }\end{array}$ & $\begin{array}{l}1 / 5^{\text {th }} \text { of the remainder of the auction money } \\
\text { after the shares of land, and licence. } \\
\text { Rs. } 85,760\end{array}$ & Mr P (the gem merchant, mentioned above) \\
\hline $\begin{array}{l}\text { Timber: wooden logs, strips and "kakilla" (a } \\
\text { special plant to fill the gaps between logs and } \\
\text { strips so that the walls would not collapse into the } \\
\text { wood) necessary for wall building in the pit. }\end{array}$ & $\begin{array}{l}1 / 5^{\text {th }} \text { of the remainder of the auction money } \\
\text { after the shares of land, licence, and water } \\
\text { engine. } \\
\text { Rs. } 68,608\end{array}$ & $\begin{array}{l}\text { Mr R (a businessman in the town, not a gem } \\
\text { merchant, though invested in a few gem } \\
\text { mines) }\end{array}$ \\
\hline $\begin{array}{l}\text { Tools: supply of all mining tools required for the } \\
\text { pit, except for water engine and its running cost. } \\
\text { All these tools, if in good conditions, go back to the } \\
\text { owner after the venture. }\end{array}$ & $\begin{array}{l}1 / 5^{\text {th }} \text { of the remainder of the auction money } \\
\text { after the shares of land, licence, water engine, } \\
\text { and timber. } \\
\text { Rs. } 54,886\end{array}$ & $\begin{array}{l}\text { KM (the headman of this particular pit). } \\
\text { However, it is not always necessary that the } \\
\text { headman should provide the tools. It could be } \\
\text { from anybody, most often from a gem } \\
\text { merchant) }\end{array}$ \\
\hline $\begin{array}{l}\text { Tea: tea and "something to eat" (often something } \\
\text { like sugar buns, curry buns, or curry rotti) twice a } \\
\text { day for all pit workers. }\end{array}$ & $\begin{array}{l}1 / 5^{\text {th }} \text { of the remainder of the auction money } \\
\text { after the shares of land, licence, water engine, } \\
\text { timber, and tools. } \\
\text { Rs.43,909 }\end{array}$ & Mr P (the gem merchant, mentioned above) \\
\hline $\begin{array}{l}\text { Headman's labour: the most experience and } \\
\text { respected labourer in the gang and deemed to } \\
\text { posses the skills of expertise of all aspects of gem } \\
\text { mining, especially correct techniques of wall } \\
\text { building. }\end{array}$ & $\begin{array}{l}1 / 10^{\text {th }} \text { of the remainder of the auction money } \\
\text { after the shares of all other forms of capital } \\
\text { except labour. } \\
\text { Rs.17,564 }\end{array}$ & KM (mentioned above) \\
\hline $\begin{array}{l}\text { Labour: } 8 \text { pit workers in this pit. Pit workers are } \\
\text { not paid wages for their work. They risk their } \\
\text { labour for a potential share of auction money, } \\
\text { which accrues only if gems are found. However, } \\
\text { they on their own, may arrange a subsistence } \\
\text { payment called "weekly cash" with anybody they } \\
\text { wish. }\end{array}$ & \multicolumn{2}{|c|}{$\begin{array}{l}\text { Share of work: the remainder of the auction money after the shares of all other forms of capital, } \\
\text { divided equally between the } 8 \text { workers involved in the pit. } \\
\text { Rs. } 19,759 \text { for each worker. } \\
5 \text { of these workers have arranged subsistence expenses with various parties in the town and } \\
\text { nearby villages. That said they pay half of their share (so called expense half) to the person who } \\
\text { had been paying them so called "weekly cash" during the venture. Three young pit workers, who } \\
\text { still enjoyed the dependence on their parents, had opted not to go for weekly cash and are } \\
\text { getting the whole "share of work" }\end{array}$} \\
\hline
\end{tabular}


Fig. 2, further illustrated in Table 1, shows a formula of appropriation to distribute the sales proceeds (the auction money) among various forms of capital. Interestingly, this formula would never be discussed or agreed upon explicitly before the various parties enter into a gem mining venture but it is a traditional practice that everybody in the field is supposed to know and accept, and applied with only very minor differences between different gem pits. According to this calculative doxa, the various forms of capital invested in a gem pit are classified and ranked into seven major categories (see Table 1). As a classificatory schema, this formula provides a calculative logic of structuring the field capital into a hierarchical order of stake. Thus, land is always placed as the top most form of capital and claims the first one fifth of the auction money. All other forms of capital contributions, as a gem merchant commented, are "appropriately rewarded according to the tradition", which designates the relative place of each category in the hierarchy of capital which, in turn, decides their relative return. Labour has always been at the bottom of the ladder and can claim only what is left after other forms of capital has appropriated their stakes of higher order. The 'share of work' as the final remainder of the auction money is equally divided among the workers in the pit.

Gem merchants' presence within this schema of capital is dominating. They would typically own more than one form of capital and reproduce their structural power by appropriating and reinvesting a bigger portion of the auction money. It should also be noted that a gem-mining venture is organised as a pure "game of gambling", 8 where different players assume different stakes and pool their capital for a collective return at the end of a single venture. The implicit social contract is such that each player agrees to contribute one or more of the above categories of capital until the end of the venture. Terms of contract are implied and well understood as a set of habitus. For example, the landowner would simply offer the land and bear no further expense other than the relatively minor costs of performing the bahirawa puja (a ritual ceremony performed to ask permissions from the gods and demons believed to possess the land and its precious stones). The one who claims for the 'share of licence' (normally the gem merchant who initiates and organises the venture) should bear all the contingent costs of obtaining the government licence for the gem pit, which include the licence fee plus all "other payments" (bribes and gifts) made to various state officers to speed up the process and to clear various bureaucratic bottlenecks. Once these expenses have been incurred, the financial commitments of the licence holder and the landowners are over. On the other hand, the social commitments of the contributors of the water pump and fuel, timber, tools and tea are on-going and should be supplied as required by the pit operations. Although there are no sophisticated calculations involved, the field actors have a 'common sense' of resource consumption by the pit operations, as manifested in a set of habitus related to the "correct way of doing pit work", such as "every riyana [a doxic unit of measurement equivalent to half a yard] of digging need four long logs and 8 short logs ... and a typical gem pit in this area needs around three tipper-trucks of timber" (which is provided by the relevant party on a piece-meal basis as the pit work progress, mostly in three occasions: one tipper-truck at a time). These categories of mining capital are mainly economic and draw on the relative wealth of the people involved but also demonstrate certain features of social and cultural capital, in that "everybody just can't come and buy our fortune. They should be one among us who we can trust", said a gem merchant. That said,

\footnotetext{
8 "It's [gem mining] like playing 'buruwa' [a form of gambling popular among locals, with equal odds of winning and losing]. You never know what you get. You may be lucky enough and have a 'good stone' valuable enough to feed even your grandchildren. Or you can be so unlucky and lose everything you put into it and end up just washing up muddy soil for nothing. It all depends on your 'paw pin' [the balance of bad and good karmas] you did in this and previous lives": (from a gem merchant on the fortunes of gem mining).
} 
"getting together for a new venture" always takes place through prior experience and other social connections that make them suitable to "share collective fortunes and misfortunes".

Gem mining is still a pre-capitalistic form of production where labour is not sold in the market for a wage and the labour process is not subordinated by technologies of governance. In fact, labour is exposed to higher risk in this game of gambling because, as illustrated in Fig. 2, a relatively smaller amount of auction money is left after appropriating the shares of all other forms of capital. However, there is a particular mechanism that labourers (if they wish) can choose to minimise risk and provide a consistent subsistence. They often negotiate for what is called 'weekly cash'. A labourer can thus arrange with someone in the village, often a government servant or other person with a relatively higher and regular income, to pay him a definite amount of money every week for subsistence (Rs. 200 at the time of the fieldwork) in return for what is called "expense half" (i.e. half of the "share of work"). In our example, above, the "share of work" was Rs. 19,759 of which half (Rs. 9880) was paid to the provider of these weekly cash as the "expense half". It should also be noted that it is the responsibility of individual workers, if they wish, to arrange their own "expense half".

In this way, the calculative template applied in the appropriation of auction money vividly demonstrates how a wider set of power relations, which articulate the structural dynamics of the field, is articulated within a specific set of material practices, and how such wider structures of power are reproduced within the cognitive schema of social agents to make such structures of domination and exploitation 'natural'. The theoretical implications of this empirical account will be discussed further in the synthesis and conclusion section in the light of Bourdieu's logic of practice and his sociology of symbolic forms. However, before that, a discussion on 'absence of accounting' and 'resistance' would fill some gaps in the analysis so far.

\section{Absence of accounting}

Gem mining in Sri Lanka is a peculiar case of "absence of accounting" (Choudhury, 1988; Catasús, 2008; Jacobs and Kemp, 2002; Jayasinghe and Thomas, 2009), as we know it elsewhere, and the presence of a peculiar form of accounting. The only form of 'accounting' (in a broader sense) present here is the "sheet of appropriation", that accounts for the return that each form of capital to venture is 'traditionally' entitled. Thus, the gains of the venture are only cognised and understood in terms of these shares, which is just a share of the sale proceeds (auction money) rather than a calculated profit/loss. For the venture, no record was kept regarding how much money was spent on tea, timber, tools or anything else for that matter. The venture has neither been defined as an accounting entity of any form nor has it gained a distinct structural separation from its social context, a status that firms in modernity have been able to achieve. That said, the venture is defined not in any accounting sense but as a social contract into which each form of capital is entered. How much each form of capital get as its return is determined neither by the 'accounting or opportunity costs' of that capital nor by any costs and benefits attributed to the venture but by the relative positioning of each form of capital in the field of capital. At its best, according to the nature of this social contract, the notion of profit, at least theoretically, can only accrue at the level of individual capital providers. For example, it is possible that a timber provider, on his own, can keep a record of all expenses that $\mathrm{s} /$ he incurred on a single venture and then compare it with his/her "share of auction money" to calculate his individual profit/loss. This could even be the case of all other 'forms of capital'. However, according to my field observations, neither of those capital providers bothers to calculate such a profit. The "share of auction money" instead seems to work as an assessment of their 'pow-pin' (the balance between good and bad karma). As a gem merchant who claims for the share of tea, timber and also the licence in a particular gem mine commented: 
"I have told Hamzudin (owner of a tea shop in the Rakwana town) to provide the guys with tea and buns or something else enough for eight people twice a day. Once a week or so, I settle my owes with Hamzudin. ... No, I don't keep a record of them. ... Profit?. ... Yes, I have been making good money; you can see that. Can't you? (he looks around to take my attention to his stock of luxurious furniture and the big house). Everybody knows that all these are gem money. ... If you put your money in a mine, you don't know what you get, you will get what you are destined to get. So, just spend your money on what you are supposed to do, beyond that it is not for us but for the God Saman (the patron god of Sabaragamuwa, the gem mining province). ... Thanks god, I of course manage without books, don't I? I got many things that I have never dreamed of before!"

So, the question is "Why is there no accounting here?" (Choudhury, 1988, p. 549; see also Catasús, 2008, p. 1007). In this empirical case at least, the answer lies in the ideological and structural apparatuses of the field and the historical construction of the economic activity as a field specific game, rather than in the "performative" and/or "ostensive" aspects of accounting (see Catasús, 2008). In other words, the substantive rationale of the absence of accounting is explained not so much by ostensive or performative aspects of what is absent, but rather by the structural and practical logics of the field within which accounting is not deemed to be necessary ("I of course manage without records, don't I?").

Historically the field of gem mining has been constructed as a "game of gambling" where each form of capital takes its own stake against the odds of the nature (i.e. natural possibility of finding a valuable gem articulated in terms of religious ideologies), and it is this doxic ideology of gem mining as a collective (and individual) gamble that negate record keeping as a practice, at least at the level of individual capital providers. By its very nature, venture outcomes (finding a valuable gem) has not been understood to have any causal connections with capital invested; instead the venture outcomes are ideologically related to the collective (and individual) karma (paw-pin) or luck. Thus, investment and practices of gem mining are not driven by any ideology of profit or any other economic measures of efficiency that demands practices of record keeping and comparing costs and revenues. Behind this non-economism embedded in the absence of accounting, there lies the nonsecular acceptance of uncontrollability of one's destiny.

Apart from these ideological conditions, there also exists a set of structural conditions that negates the presence of accounting beyond the "sheet of appropriations". Still in the form of a pre-modern economic enterprise characterised by rentier capital ${ }^{9}$ relations, gem mining, on the other hand, has not yet gained a distinct 'organisational boundary and a structure' within which class distinctions are institutionalised as a mode of production. Ostensive and performative dimensions of modern accounting pre-requires such a mode of production which is still absent in Sri Lankan gem mining. Instead, field is structured as a series of economic ventures that a selected set of social actors enters into through their social relations that pre (and post) exist a particular venture. Thus, in contrary to a western mine, gem mines in Sri Lanka have no structural prerogatives to instigate a system of

\footnotetext{
9 The gem pit or the venture does not "buy" any of these capitals. Neither a particular form of dominant capital "buy" the other forms of capital assuming a role of entrepreneurship, as it is commonly assumed in western economics. Instead they all pool together for the particular gem pit as a single venture. After the venture, for example, the land is still with the land owners (which s/he may put it back to other uses), the water engine and tools are still with their owners (which they often provide to a new venture). Those who offer labour, tea, timber, and expense half (working capital providers, in the accounting jargon I learnt from the West) are the parties with no residual value of their capital but only the relevant share of auction money.
} 
accounting therein. They are structured and governed, on the one hand, through power relations that extend beyond the gem mine into the patronage power relations in the society. Within such a wider set of power relations, the existing form of accounting, the "sheet of appropriation", function as the symbolic means through which structural properties of the field are cognised, communicated, reproduced and transformed into a set of practical dispositions that orient day-today work practices, domination and resistance.

On the other hand, as we discussed earlier, the labour process is ritualistic and structured by a set of habitus and bodily hexis. Ritualistic organisation of labour process in this way is, therefore, a very strong hegemonic form of subsumption, although it may not qualify as real subsumption of labour (see Marx, 1976, p. 1021; and also Burawoy, 1979, p. 15). As far as there is a field specific calculative mechanism to exploit its surplus value by the dominating forms of capital, and as far as there is no "labour aristocracy" (Moorhouse, 1978) to dominate the field specific logic of appropriation, there exists no real necessity for other forms of accounting, especially those forms through which real subordination is achieved in its Western counterparts. Instead, the habitus establishes a particular form of accounting as represented by the "rules of the game".

\section{Domination, subjugation and resistance}

The discussion so far revealed that the field of gem mining and gem pit operations have been structured as a dominating structure through a set of habitus, doxa, bodily hexis, and a particular calculative template that translates the relative positioning of different forms of capital into a set of practical dispositions of appropriating field's surplus value. As structuring structures, these forms of embodiments and forms of capital structure the field into a social space within which symbolic violence by a dominating form of capital ismadepossible. However, such a dominating structure should not be conceptualised as a whole encompassing structure of domination that leaves no space for resistance by the subalterns. Instead, a field should be understood as a structure within which even the subaltern social actors do enjoy an agency of strategising and resisting. That's why Bourdieu's reflexive sociology conceives a field as a 'game': a structural frame for interaction between conflicting actors and their interests providing a political space for actors to strategise and resist. However, within such a dominating structure, resistance mostly take place in the form of what Scott (1985, 1990, see also Alawattage and Wickramasinghe, 2009) calls "everyday forms of resistance" or "hidden transcripts":

"the prosaic but constant struggles between the peasantry and those who seek to extract labour, food, taxes, rents, and interests from them. Most of the forms of this struggle takes stop well short of collective outright defiance ... and they typically avoid any direct symbolic confrontation with authority or elite norms" (Scott, 1985, p. 29).

As such, they are not collective forms of resistance and I could not find any instances (or any story of such an instance) of collective engagement of labour to steal gems from the pit or any other forms of collective defiance of the existing relations of production in the field. Furthermore, it appears that "stealing from our own pit" does not make any sense for them in a collective sense. Nevertheless, there are ample 'stories' of individual defiance of this collective doxa despite the very high risk involved in such an attempt. As one worker commented,

"yes if you are very very lucky, and so clever to hide it, you find a chance to smuggle a gem while working in the bottom of the pit, but you never get that chance when you are washing the illama in front of everybody. If you smuggle one, keep it for so long, many years, before trying to sell it. Otherwise, you will lose 
your friends, and may even lose your life as what happened to D (a gem pit worker found dead in a gem pit)"

The most apparent and obvious form of resistance to the structural logics of domination and subjugation is to leave the game altogether. Majority of those who enter the field as workers (mainly school leavers) leave it as soon as they find something else. As a headman (too old to join the Army perhaps) once commented, "It is increasingly becoming difficult to organise a work gang, because everybody now joins the Army ${ }^{10}$. Many die in the war but at least their children or parents get their salary until they live".

Resistance can also be seen in the form of an alternative form of organising a gem pit venture: a structural alternative. These are called "hora patal": illicit shallow pits often run solely by a gang of workers in the middle of government forests without a licence and without contributions from other forms of capital. This is possible mainly due to the shallowness of the gem pit and consequent simplicity of the pit operations in terms of resource requirements. Although possibility of finding a gem is lower in this sort of gem pits than in the deep pit mining, and although there is a high risk of "police raids, physical injuries from police beatings, imprisonment and fines", there is an increasing tendency, especially of young school leavers, to engage in these alternative forms of gem mining. As a gem merchant commented (not in a negative or complaining but rather in a philosophising tone):

"Some young guys would find some tools, collect some foods enough for a week or so, disappear into the forest and may return with a good lot of gems, or may return empty handed, or even end up in the jail for six months. They don't care. ... Yes, they should try their luck in the jungle and would bring us some gems if they find them"11

The point bringing the resistance to discussion here is that although calculative templates, habitus, bodily hexis and doxa, should be understood as 'structuring structures' they should never be understood as whole encompassing structures of domination. They always leave ample opportunities for prosaic forms of resistance that make the field always an imperfect structure of domination and subjugation. It is this imperfection of the game that always makes a particular field historically dynamic.

\section{Synthesis and conclusions: logic of calculative practices}

So far, in the empirical sections above, I have discussed how a set of field-specific habitus has structured the presence of calculative and control practices of some kinds and the absence of other kinds. However, this does not mean that the social logic of the presence and absence of various calculative and control practices can be fully explained by the mere empirical specification of such habitus. Instead, an empirical account of habitus in a given field of production would provide an insight into "what gives practices their relative autonomy with respect to external determinations of the immediate present" (Bourdieu, 1990b, p. 56). Such an empirical account would also explain

\footnotetext{
10 During the time of fieldwork, the country was in the middle of a civil war with separatist Tamil Tigers of the northern part of the country. The Government Army was in a shortage of soldiers and provided the largest source of employment for unemployed youths in the poverty laden villages and a bare minimum education of up to grade 6 was more than enough to be a soldier and earn a permanent income.

11 One important thing that gem merchants establish before buying a gem is its source. As such it is difficult and dangerous to sell a 'stolen gem'. However, merchants are more than ready to buy gems from "hora-patal". Illegal gemmining is a 'state imposition' for which field actors have little respect. As far as the illegal gem miners can handle the police raids of their mines, selling a gem from a illegal mine is not a problem in the field. This means, there is no field definition of 'illegal-gems' but 'illegal gem pits'.
} 
how habitus, as "a past which survives in the present and tends to perpetuate itself into the future by making itself present in practices structured according to its principles" (Bourdieu, 1977, p. 82), offers a set of schemes of perception, cognition, evaluation, classification, and also motor patterns and performative routines, which "[tend] to guarantee the 'correctness' of practices, and their constancy over time, more reliably than formal rules and explicit norms" (Harker and May, 1993, p. 174). Such an empirical account on its own, however, would not reveal the 'deep structures' of domination and subordination in social life, alongside which the logic of calculative practices can better be understood. Thus, calculative and control practices, according to Bourdieu's (1990b) logic of practice,

cannot be deuced either from the present conditions which may seem to have provoked them or from the past conditions which have produced the habitus. ... They can therefore only be accounted for by relating the social conditions in which the habitus that generated them was constituted, to the social conditions in which it is implemented (p. 56).

This means that practices are products of dispositions intersecting with the dynamics and structures of a particular field, and practices reflect the structure of that encounter. This relationship is dialectical and, hence, calls for analyses of both (1) the structure of the relevant field in terms of its power relations and (2) the habitus of the agents involved in the field (Swartz, 1997, p. 141). In one of his classic works, Distinction (Bourdieu, 1984, p. 101), Bourdieu formulates following equation to summarise this dialectical logic of practices:

$$
[(\text { habitus })(\text { capital) }]+\text { field }=\text { practice }
$$

This equation highlights the interlocking nature of habitus, capital and field and their dialectical construction of practices as well as the epistemological centrality of practices in the articulation of deep cognitive and social structures that underlie the practices pertaining to a particular field. Thus the field logic of practices and an analysis of field, according to Bourdieu's reflexive sociology (Bourdieu and Wacquant, 1992, pp. 104-105), involves three necessary and internally connected moments: analysis of the positions of field vis-à-vis the field of power (i.e. the current state of the field); mapping out the objective structure of the relations between the positions occupied by the agents or institutions who compete for the legitimate forms of domination, control and appropriations (i.e. forms of capital); and analyses of the different systems of dispositions (habitus, bodily hexis and doxa) that the agents of a field have acquired through internalising a determinate type of social and economic condition. However, the structured systems of practices (related to field and capital), expressions and dispositions of agents are methodologically inseparable and must be analysed together (Bourdieu and Wacquant, 1992, p. 105).

Coming back to our empirical case with this theoretical and analytical insight, the particular calculative practice of appropriating auction money is a product of this dialectic intercourse between the field structure of capital and the cognitive structures of its agents. As a form of institutionalised practice, this calculative template of appropriations (see Fig. 2) demonstrates how the field is structured according to the relative positioning of various categories of capital. Thus, the social order within which gem mining is conditioned is a dominating structure of hierarchically differentiated categories of resources which, for Bourdieu (1991b, p. 230), are capital because they function as the "social relation of power ... over the accumulated product of past labour ... and thereby over the mechanisms which tend to ensure the production of a particular category of goods and thus over a set of revenues and profits." The hierarchical stratification of capital manifested by this particular calculative practice is internally connected to the wider relations of power operating 
in and beyond the field of gem mining, and within the cultural political economy of Sri Lankan village landscape. That said, the power of land owners and gem merchants to appropriate a larger proportion of the auction money over other forms of capital (including labour) stems from the embodiment of the social order (i.e. the field of power) manifested by historically accumulated economic capital (such as possession of financial capital, big houses, automobiles, and other symbols of wealth and power), patronage relations and other forms of social capital (relations with government officers, for example) within a set of habitus and related calculative practices.

In this way calculative practices and templates become instruments of symbolic manipulation or symbolic forms and processes that reproduce social inequalities. As already noted, such symbolic systems simultaneously perform three interrelated but distinct functions: structuring structures (cognition), structured structures (communication) and instruments of domination (social differentiation).

Calculative templates and procedures, as 'structuring structures', are instruments for knowledge and gnoseological construction of objective world; they are ameans by which to order and understand the social world. In this sense, the calculative template used in appropriating auction money is not simply a technical means of calculating the stake of each category of capital but a structuring structure. It exerts a structuring power to construct reality, which tends to establish a gnoseological order of the social world (see Bourdieu, 1979, p. 79). Such symbolic systems are also 'structured structures', whose internal logic channels deep structural meaning shared by all members of a field. As conceptual systems, such calculative templates and procedures, therefore, function simultaneously as instruments of communication and as instruments of knowledge (Swartz, 1997, p. 83), and they are the "instruments par excellence of social integration: as instruments of communication and knowledge they make possible the consensus on the sense of the social world which makes a fundamental contribution toward reproducing the social order" (Bourdieu, 1979, p. 79). Thus, the sheet showing the appropriation of auction money not only constructs a gnoseological structure of the field as an integration of the interests of differentiated categories of capital but also contributes towards a homogeneous conception of the game of gem mining as a collective venture (against the nature and the will of gods and demons) with a distinctive stake for each category of capital.

According to Bourdieu (1979, p. 80), symbolic systems, as structured and structuring instruments, fulfil their political function as instruments that legitimate domination. They help to ensure the domination of one class of capital over others, and lead, in Weberian terms, to the 'domestication of the dominated'. In other words, calculative templates and procedures, as symbolic systems, legitimate social ranking by encouraging the dominated to accept the existing hierarchies of social distinction. For example, in our empirical case, none of the pit workers ever complained about the apparent 'discrepancies' in the appropriation of auction money but took it for granted that there was no problem with the system as it stood; it is the way it has always been and, therefore, should always be. They believe, for the future, that "depending on our own karma and wise investment of whatever the money we receive, we can be gem merchants; many of those big merchants have started like us". The social hierarchy that was apprehended, communicated and reproduced through symbolic systems of calculations has been internalised as a legitimate system that provides everyone with fair opportunities for progress over the social hierarchy by transforming their current labour power (one form of capital) into other forms of capital with a higher symbolic power of appropriation. Bourdieu calls this form of domination, or legitimation of domination, symbolic violence which, in contrast to overt violence, is gentle, invisible violence, unrecognised as such, chosen as much as undergone, that of trust, obligation, personal loyalty (to patrons as well as to the system) ... of all the virtues honoured by the ethic of honour (Bourdieu, 1990b, p. 127). 
These cognitive, communicative and dominating powers of calculative templates and procedures, however, do not occur in the form of an 'illocutionary force' but are defined in and by the very structure of the field within which beliefs are produced and reproduced (Bourdieu, 1979, p. 83). Thus, there is an inseparable dialectic between calculative practices and the structures of the field: calculative templates and procedures, on the one hand, are products of the structural configuration of the relevant field in a particular temporal and spatial phase of evolution and, on the other, are the symbolic means through which the same structural configuration is understood, communicated and reproduced. That said, they lie, as symbolic systems, in the middle of the (subjective) cognitive structures of the agents and the (historically) objective structures of the social system. In this way, they constitute the system of habitus and doxa that orients (rather than determines) day-to-day work practices, modes of domination and resistance. For example, the field of gem mining in Sri Lanka, through a definite mode of calculation related to the appropriation of auction money, is thus structured as a particular combination of seven categories of capital with distinctive stakes and powers of appropriations. This field-specific calculative logic has excluded notions of profit beyond the 'auction proceeds', leaving out any necessity for detailed cost calculations and controls at the point of production. Thus, a particular field-specific logic of calculation underlies the relative autonomy of labour process from the external control of other forms of capital.

Therefore, this paper shed light on the accounting research that attempts to understand idiosyncrasies of accounting, emphasising the power of Bourdieu's sociology of symbolic interests to theorise the presence and the absence of particular forms of calculative and control practices. My main argument is that calculative templates and procedures constitute a field specific logic and they are the symbolic means through which structural properties of the field are cognised, communicated, reproduced and transformed into a set of practical dispositions that orient day-today work practices, domination and resistance. This means, as Hamilton and ó hógartaigh (2009, p. 917) also argues, existential and non-existential rationalities of particular forms of accounting and control rituals "emanate from the practice of the field", which in turn to be found in and to be bound by systems of durable and transposable dispositions and bodily schemata (i.e. habitus, doxa and bodily hexis), on the one hand, and the structural conditions of the field manifested by the power relations among various forms of capital, on the other.

This is where Bourdieu's reflexive sociology become immensely useful vis-à-vis contemporary analyses of "how forms of accounting emerge from, sustain and modify wider institutional and social structures" (Hopwood, 2000, p. 763; see also Hamilton and Ó hÓgartaigh, 2009, p. 917). As illustrated in this case study, the potential of Bourdieu's sociology stems from its capacity to connect "carnal" (i.e. bodily and corporeal, see Wacquant, 2004a, 2004b) dimensions of control and calculative rituals with wider relations of power (i.e. capital) in a particular field. It helps us, on the one hand, together with rich ethnographic accounts, to understand accounting as a carnal practice (i.e. practices so inseparably in the bodies and souls of people who carry them out that those bodies and souls are defined by those accounting practices), and its defining principles (such as the notion of true and fair view and field-specific reporting templates) as historical products of such carnal practices (see also Hamilton and Ó hÓgartaigh, 2009). On the other hand, it also helps us to see accounting as a powerful symbolic system through which structural properties of the field are cognised, communicated, reproduced and transformed into a set of practical dispositions that orient day-to-day work practices. Thus, for example, we see the relations of production (i.e. appropriation of surplus value) through the profit and loss account and we understand the structure of capital through the balance sheet. Such accounting templates, as symbolic systems that defines the practices, provide us with a particular way (or perhaps the only way) of seeing and accepting the world, and hence they become the symbolic means through which structural 
properties of a field is reproduced. And it is those structural properties that necessitate the presence of particular form of calculative practices while negating the presence of any other form structurally unnecessary. In this way Bourdieu's reflexive sociology is helpful in understanding the practical and structural logics of the presence and absence of accounting.

\section{References}

Alawattage C, Wickramasinghe D. Weapons of the weak: subalterns' emancipatory accounting in Ceylon Tea. Accounting, Auditing \& Accountability Journal 2009;22(3):379-404.

Baxter J, Chua WF. Be(com)ing the chief financial officer of an organisation: experimenting with Bourdieu's practice theory. Management Accounting Research 2008;19(3):212-30.

Bourdieu P. Outline of a theory of practice. Cambridge: Cambridge University Press; 1977.

Bourdieu P. Symbolic Power. Critique of Anthropology 1979;4(1):77-85.

Bourdieu P. Distinction: a social critique of the judgement of taste. Cambridge, Mass: Harvard University Press; 1984.

Bourdieu P. The forms of capital. In: Richardson JG, editor. Handbook of theory and research for the sociology of education. New York: Greenwood Press; 1986. p. 241-58.

Bourdieu P. Homo Academicus. Cambridge: Polity Press in association with Basil Blackwell; 1988.

Bourdieu P. Social space and symbolic power. Sociological Theory 1989;7(1):14-25.

Bourdieu P. In other words: essays towards a reflexive sociology. Stanford, CA: Stanford University Press; 1990a.

Bourdieu P. The logic of practice. Stanford, Calif: Stanford University Press; 1990b.

Bourdieu P. Fourth lecture. Universal corporatism: the role of intellectuals in the modern world. Poetics Today 1991a;12(4):655-69.

Bourdieu P. Language and symbolic power. Cambridge, Mass: Harvard University Press; 1991b.

Bourdieu P. Sociology in question. London: Sage Publications; 1995.

Bourdieu P. Practical reason. Stanford: Stanford University Press; 1998.

Bourdieu P. The weight of the world: social suffering in contemporary society. Oxford: Polity; 1999.

Bourdieu P, Wacquant L. An invitation to reflexive sociology. Chicago: University of Chicago Press; 1992.

Boyns T, Edwards JR. Change agents and the dissemination of accounting technology: Wales' basic industries, C.1750-C.1870. Accounting History 1996;1(1):9-34.

Burawoy M. Manufacturing consent: changes in the labour process under monopoly capitalism. Chicago: The University of Chicago Press; 1979.

Burawoy M. The extended case method. In: Burawoy M, editor. Ethnography unbound: power and resistance in the modern metropolis. Berkeley: University of California Press; 1991. p. 271-90. 
Catasús B. In search of accounting absence. Critical Perspectives on Accounting 2008;19:1004-19.

Central Bank of Sri Lanka, Annual Report. Central Bank of Sri Lanka, Colombo; 2009.

Choudhury N. The seeking of accounting where it is not: towards a theory of non-accounting in organizational settings. Accounting, Organizations and Society 1988;13(6):549-57.

Cooper C. Critical accounting in Scotland. Critical Perspectives on Accounting 2002;13(4):451-62.

Cooper DJ, Everett J, Neu D. Financial scandals, accounting change and the role of accounting academics: a perspective from North America. European Accounting Review 2005;14(2):373-82.

De Beelde I. Financial reporting in Belgium: case studies on collieries, 1900-1950. Accounting History 2000;5(1):85-110.

Emirbayer M, Johnson V. Bourdieu and organizational analysis. Theory and Society 2008;37(1):1-45.

Everett J. The politics of comprehensive auditing in fields of high outcome and cause uncertainty. Critical Perspectives on Accounting 2003;14(1-2):77-104.

Everett J. Exploring (false) dualisms for environmental accounting praxis. Critical Perspectives on Accounting 2004;15(8):1061-84.

Everett J. Editorial proximity equals publication success: a function of rational self-interest or good-faith economy? Critical Perspectives on Accounting 2008;19(8):1149-76.

Fogarty TJ. The stratification of academic accounting in the USA: a theoretical and empirical evaluation of institutional reproduction. Accounting Education 1998;7(1):3-20.

Foucault M. Discipline and punish: the birth of the prison. Aylesbury: Penguin Books; 1979.

Free C, Macintosh NB. Bourdieu's logic of practice theory: possibilities for research on management accounting and control. Ontario, Canada: Queen's University School of Business; 2009. pp. 1-40, Research Paper No 02-09.

Goddard A. Budgetary practices and accountability habitus: a grounded theory. Accounting, Auditing \& Accountability Journal 2004;17(4):543-77.

Hamilton G, Ó hógartaigh C. The third policeman: the true and fair view, language and the habitus of accounting. Critical Perspectives on Accounting 2009;20(8):210-20.

Harker R, May SA. Code and habitus: comparing the accounts of Bernstein and Bourdieu. British Journal of Sociology of Education 1993;14(2):169-78.

Hopwood AG. Understanding financial accounting practice. Accounting, Organizations and Society 2000;25:763-6.

Jacobs K. Class reproduction in professional recruitment: examining the accounting profession. Critical Perspectives on Accounting 2003;14(5):569-96.

Jacobs K, Kemp J. Exploring accounting presence and absence: case studies from Bangladesh. Accounting, Auditing \& Accountability Journal 2002;15(2):143-61. 
Jayasinghe K, Thomas D. The preservation of indigenous accounting systems in a subaltern community. Accounting, Auditing \& Accountability Journal 2009;22:351-78.

Kurunmaki L. Making an accounting entity: the case of the hospital in finnish health care reforms. European Accounting Review 1999a;8(2):219-37.

Kurunmaki L. Professional vs financial capital in the field of health care - struggles for the redistribution of power and control. Accounting, Organizations and Society 1999b;24(2):95-124.

Lee T. Shaping the US Academic accounting research profession: the American accounting association and the social construction of a professional elite. Critical Perspectives on Accounting 1995;6(3):241-61.

Lee TA. Anatomy of a professional elite: the Executive Committee of the American Accounting Association 1916-1996. Critical Perspectives on Accounting 1999;10(2):247-64.

Lee TA, Williams PF. Accounting from the inside: legitimizing the accounting academic elite. Critical Perspectives on Accounting 1999;Vol. 10:867-95, No. 6.

Lounsbury M. Institutional rationality and practice variation: new directions in the institutional analysis of practice. Accounting, Organizations and Society 2008;Vol. 33:349-61, No. 4-5.

Lounsbury M, Ventresca M. The new structuralism in organizational theory. Organization 2003;10(3):457-80.

Lukka K, Granlund M. The fragmented communication structure within the accounting academia: the case of activity-based costing research genres. Accounting, Organizations and Society 2002;27(1-2):165-90.

Macintosh NB. Management accounting and control systems: an organizational and behavioural approach. Chichester: Wiley; 1994.

Marx K. Capital: a critique of political economy, vol. 1. London: Penguin; 1976.

Moorhouse H. The marxist theory of labour aristocracy. Social History 1978;3:61-82.

Neu D. Accounting for public space. Accounting, Organizations and Society 2006;31(4-5):391-414.

Neu D, Cooper DJ, Everett J. Critical accounting interventions. Critical Perspectives on Accounting 2001;12(6):735-62.

Neu D, Friesen C, Everett J. The changing internal market for ethical discourses in the Canadian CA profession. Accounting, Auditing \& Accountability Journal 2003;16(1):70-103.

Neu D, Ocampo Gomez E, Graham C, Heincke M. "Informing” technologies and the World Bank. Accounting, Organizations and Society 2006;31(7):635-62.

Oakes LS, Townley B, Cooper DJ. Business planning as pedagogy: language and control in a changing institutional field. Administrative Science Quarterly 1998;43(2):257-93.

Oakes LS, Young JJ. Reconciling conflict: The role of accounting in the American Indian Trust Fund debacle. Critical Perspectives on Accounting 2010;21:63-75.

Rahaman AS, Everett J, Neu D. Accounting and the move to privatize water services in Africa. Accounting, Auditing \& Accountability Journal 2007;20(5):637-70.

Ramirez C. Understanding social closure in its cultural context: accounting practitioners in France (19201939). Accounting, Organizations and Society 2001;26(4-5):391-418. 
Scott JC. Weapons of the weak: everyday forms of peasant resistance. New Haven, CT and London: Yale University Press; 1985.

Scott JC. Domination and the arts of resistance: hidden transcripts. New Haven, CT and London: Yale University Press; 1990.

Shenkin M, Coulson AB. Accountability through activism: learning from bourdieu. Accounting, Auditing \& Accountability Journal 2007;20(2):297-317.

Snow DA, Morrill C, Anderson L. Elaborating analytic ethnography: linking fieldwork and theory. Ethnography 2003;4(2):181-200.

Strauss A, Corbin J. Basics of qualitative research: grounded theory procedures and techniques. Newpury Park: Sage; 1990.

Swartz D. Culture \& power: the sociology of Pierre Bourdieu. Chicago; London: University of Chicago Press; 1997.

Swartz D. Bringing Bourdieu's master concepts into organizational analysis. Theory and Society 2008;37(1):45-53.

Vaughan D. Bourdieu and organizations: the empirical challenge. Theory and Society 2008;37(1):65-82.

Vent G, Milne RA. Cost accounting practices at precious metal mines: a comparative study, 1869-1905. Accounting History 1997;2(2):77-105.

Vent G, Milne RA. Accounting practices of the St. Joseph Lead Company: 1864-1900. Accounting, Business and Financial History 2000;10(2):97-128.

Wacquant L. Towards a reflexive sociology: a workshop with Pierre Bourdieu. Sociological Theory 1989;7(1):26-63.

Wacquant L. Ethnografeast: a progress report on the practice and promise of ethnography. Ethnography 2003;4(1):5-14.

Wacquant L. Following Pierre Bourdieu into the field. Ethnography 2004a;5(4):387-414.

Wacquant L. Body \& soul: notebooks of an apprentice boxer. Oxford; New York: Oxford University Press; 2004b.

Willis PE. The ethnographic imagination. Oxford: Polity Press; 2000.

$\mathrm{Xu} Y, \mathrm{Xu}$ X. Social actors, cultural capital, and the state: the standardization of bank accounting classification and terminology in early twentieth-century China. Accounting, Organizations and Society 2008;33(1):73-102. 